This is the uncorrected version of the article published subsequently as:

Nentwich, Julia C.; Poppen, Wiebke; Schälin, Stefanie; Vogt, Franziska (2013). The same and the other: Male childcare workers managing identity dissonance. In: IRS, International Review of Sociology 23, Nr. 2, p. 325-344, DOI:10.1080/03906701.2013.804295.

\title{
The same and the other: Male childcare workers managing identity dissonance
}

\author{
Julia Nentwich, ${ }^{1}$ Wiebke Poppen, ${ }^{2}$ Stefanie Schälin \\ University of St. Gallen, Switzerland \\ Franziska Vogt \\ University of Teacher Education St. Gallen, Switzerland
}

\begin{abstract}
As childcare workers, men are in a contested position. On the one hand, they are in danger of being depicted as the pedophile; on the other, they are expected to bring something new and innovative to the thus-far female-dominated field. These men are experiencing identity dissonance' and have to find ways to manage and facilitate legitimate subject positions as both childcare workers and as men. Applying a perspective of discursive positioning, this article discusses men's positioning practices in nine qualitative interviews conducted with male childcare workers in German-speaking Switzerland. We identified a total of six discursive practices that men engage in to manage identity dissonance and construct a legitimate subject position. We found that men are engaging in a greater variety of practices than have been discussed so far. Unlike findings from other studies of men in femaledominated occupations, ours do not point to a clear-cut typology with regards to hegemonic and alternative masculinities; instead they show a variety of practices that are mobilized throughout all interviews.
\end{abstract}

Keywords: masculinities; doing gender; early childhood education; discourse analysis; subject positioning

\footnotetext{
${ }^{1}$ julia.nentwich@unisg.ch

2 wiebke.poppen@unisg.ch 


\section{Introduction}

Early childhood education is a female-dominated field in which men are easily depicted as 'the other'. In Europe, more than 95\% of the trained childcare workers in nurseries are women, although the percentages of male childcare workers vary from a total of $9 \%$ in Norway to under $1 \%$ in Austria (Friis 2008). However, early childcare education is also female-dominated (Cameron 2001). From a historical perspective, working in early childhood education is closely connected to mothering, to the 'natural' character of women, and hence to femininity (Nadai et al. 2005, 43). In fact, the skills and activities attributed to the 'ideal worker' (Acker 1990) in this specific field are generally those seen as female, such as caring, nurturing, and comforting (Vogt, 2002).

The position that men occupy in this field is often contested; for instance people regularly react with surprise when they encounter a man who does not fit into the stereotypical perception of the 'teaching woman' and the 'administrating man' (Sargent 2005, 255-256). Even worse, male teachers, especially those working with young children, are often suspected of being pedophiles or pathological in other ways (Murray 1996). While women - as potential mothers - stand for 'love' and 'protection', men are seen as representing 'danger' or, as an interviewee in Sargent's $(2005,254)$ study put it: 'Women's laps are places of love. Men's are places of danger.' Thus, men working in early childhood education are perceived as somehow suspicious; they must constantly legitimize their integrity as men.

Recently, however, a critical stance on what is depicted as the 'feminization of education' (Rohrmann 2009) has gained prominence. As people interpret men's otherness to the field as something new and potentially innovative in the thus-far female-only context, masculinity becomes highly valued (Faulstich-Wieland 2011). In this light, being male, and especially being other, has become a highly cherished attribute of childcare workers, one that parents, especially, find attractive (Buschmeyer 2012). Men are expected to bring something innovative and new to these positions and to fill the so-far 'empty space of the father', which is seen as complementary to the traditional 'mother's role' filled by the female colleagues.

While men have to perform up to the norm set by the female ideal worker, and hence try to act as 'the same', they are also held accountable as members of their sex category; thus they also have to do masculinity and act as 'the other' (Murray 1996). This is what Warin (2006) has depicted as an 'identity dissonance' that has to be 'managed' (Pullen and Simpson 2009). Men might engage in boundary work and distance themselves from their female colleagues, thereby emphasizing their 'otherness' (Heintz et al. 1997; Williams 1995). Second, men 
engage in 'alternative masculinities' (Cameron 2001; Cross and Bagilhole 2002; Lupton 2000). Emphasizing their 'sameness', they 'appropriate femininity' (Pullen and Simpson 2009) as an important interpretative frame of their activities. However, neither 'masculinity' nor 'femininity' is a monolithic concept (Edley and Wetherell 1999). As masculinities shift with contexts, more recent studies emphasize the fluid and flexible aspects of practicing gender (Kelan 2010; Nentwich 2008; Nentwich and Kelan forthcoming; Pilgeram 2007; Pullen and Simpson 2009) as well as masculinities (Martin 2001; Warin 2006). Researchers are finding that men in female professions are emphasizing both sameness and difference. They are ‘jockeying for position' (Edley and Wetherell 1997).

Against the backdrop of this very recent 'performative turn' in research on men in female professions, in this paper we provide a detailed analysis of the discursive practices (Davies and Harré 1990; Gherardi and Poggio 2007) that we found in nine interviews with male childcare workers in German-speaking Switzerland. Our analysis shows that men are engaging in a greater variety of practices than have been described so far. Using discourse analysis, we identified a total of six discursive practices that men engage in to manage identity dissonance and construct a legitimate subject position. The paper is organized as follows. First, we provide an overview of the practices men use to address the dilemma of 'same' and 'other' that have been identified so far in research on men in female-dominated occupations. Second, we briefly introduce the empirical sample and methodology involved. Third, we present our analysis of discursive practices and finally we discuss their consequences in terms of resulting subject positions and managing identity dissonance.

\section{Coping with identity dissonance: Building 'male niches' and 'appropriating femininity'}

Scholars writing on men in female-dominated professions have described two major strategies men use to cope with the dissonance of having to perform as both 'the other' and 'the same'. First, men are said to 'emphasize difference'. They build 'male niches' that separate them and what they do from their female colleagues (Williams 1989). For instance, Heintz and her coauthors (1997) show that male nurses tend to label themselves as the 'ward's crane' (109), thereby emphasizing their engagement in tasks that involve lifting persons or managing angry or abusive patients. By emphasizing their physical strength and its usefulness to the team's doing a good job, they are drawing a boundary between themselves and the female nurses. Men in early childhood education have been described as engaged in giving 'high fives' or shaking hands in order to develop a more 'masculine' way of having physical contact with the 
children. They thereby distance themselves from practices they perceive as feminine, such as taking a child on their lap, or comforting a child (Sargent 2005, 256).

Men in early childhood education are also very likely to experience the effects of the glass escalator (Budig 2002; Hultin 2003; Maume 1999; Williams 1992). The empirical fact that men in female-dominated occupations are promoted fairly quickly can be interpreted as a form of boundary work: it separates men from the daily interaction with patients, children, or babies and moves them into management positions which are perceived as more in tune with hegemonic masculinity (Williams 1995). In a similar way, men tend to discursively reconstruct the 'nature' of their occupation, highlighting characteristics that emphasize masculinity instead of femininity (Lupton 2000). For instance, men working as flight attendants have been described as emphasizing safety issues as important to one's job instead of serving drinks (Simpson 2009) and male primary teachers tend to highlight the relevance of sport, as the ones who engage in the fairly 'rough games', especially with the boys (Simpson 2004), as well as being a professional in education (Simpson 2009). This 're-casting' of the job content (Simpson 2004) emphasizes difference with regards to women and hence facilitates the doing of masculinity.

Second, men in female-dominated occupations engage in alternative forms of masculinity. Here, men renegotiate and redefine what masculinity might mean with respect to their gender identity. For instance, in ten interviews with men working in various female-dominated occupations, Cross and Bagilhole (2002) found that men not only engaged in emphasizing hegemonic forms of masculinity, but also engaged in alternative masculinities. They identified with parts of their work that were traditionally perceived as feminine and also reported that they highly cherished these aspects and perceived them as rewarding. For example, men working in a female occupation explained that they can show emotions and be a caring person, which makes them more attractive to women. Four out of the ten men in that study said that engaging in tasks that have traditionally been perceived as female enriched their lives and made them more rounded personalities (Cross and Bagilhole 2002: 223). In a similar vein, Buschmeyer (2012) found that some men working in German kindergartens engage in 'doing alternative masculinity'. Alternative masculinity is defined here as explicitly opposing hegemonic masculinity and instead emphasizing characteristics such as nurturing, caring, and even mothering as important and relevant for their identity. In such situations men are said to 'appropriate femininity' (Pullen and Simpson 2009).

However, as Pullen and Simpson $(2009,561)$ show by analyzing how men in nursing and primary education are doing difference, these two strategies are not ways to fix masculine 
identities; instead they are distinctive positioning practices that enable men to 'manage' difference in a female-dominated field. This management involves both reinforcing and subverting the position of 'the other'; hence, men in female-connotated professions must enact both masculinity and femininity (Pullen and Simpson 2009). 'Managing masculinity' may mean resisting and challenging the positions that others ascribe to them, or confirming and sustaining those they ascribe to themselves. Men must do, and undo, masculinity in a particular moment (McDonald 2012) in order to cope with the 'identity dissonance' (Warin 2006) of being both 'the other' and 'the same'.

For the field of early childhood education, Warin (2006) has analyzed the negotiation practices of competing masculinities. In an in-depth analysis of one interview with a male nursery class teacher, she identifies three overlapping subject positions: the 'protector', the 'pioneer' and the 'professional expert'. As this one interviewee produced and elaborated upon these three positions, he struggled with establishing both traditional and alternative forms of masculinity. The two strategies of 'emphasizing difference' and 'appropriating femininity', which we identified earlier, both seem to be at work at the same time; they are discursive accomplishments (Wetherell and Edley 1999). Men position themselves as men or as professional childcare workers when they face specific expectations or challenges (Lupton 2000).

It is in these discursive interactions with real and imagined others that men must find ways to manage 'identity dissonance' and facilitate legitimate subject positions as both childcare worker and man. In ‘jockeying for position' (Edley and Wetherell 1997), men have to permanently find subject positions that allow for both masculinity and professional interaction with small children without becoming suspicious. However, these subject positions are not stable, fixed identities, but positions that are negotiated in discourse. Therefore, from this perspective of positioning theory (Davies and Harré 1990), the differences between engaging in 'emphasizing difference' or 'appropriating femininity' might not be as clear-cut as the literature suggests. Discourses of masculinity 'form the objects of which they speak' (Foucault 1972) and are reproduced by continuously citing the very same discourses. As 'sense-making is complex, contradictory and full of competing claims and dilemmas' (Wetherell and Edley 1999, 351), men practice both norm-compliance and resistance at the same time.

Taking this agentic subject as a starting point, we suggest re-formulating what has so far been depicted as the 'managing of masculinity'; we see it instead as the discursive maneuvers of men engaging with identity dissonance. Analyzing how men working in nurseries engage 
with this dissonance of having to perform as both 'the same' and 'the other', we were able to name six discursive practices they use to manage this dissonance. After introducing our sample and methodology in the following paragraphs we will describe these practices in greater detail and discuss their consequences.

\section{Methodology}

The empirical research project was conducted in a German-speaking area of Switzerland. In the context of a national research effort on gender equality, we are investigating (un)doing gender in nurseries ${ }^{3}$. Nurseries in Switzerland cater for children from the age of three months to six years. They are mainly privately run and financed. Employees working in nurseries are professionally trained as 'childcare workers' in a three-year apprenticeship.

Our research design involved multiple qualitative research methods: 20 interviews with nursery managers, 16 interviews with male and female childcare workers, photographic documentation of the spatial arrangements, and ethnographic (video) observations in four nurseries. Seven of the nurseries in our sample employ one or more fully-trained male childcare workers; this enabled us to conduct a total of nine interviews with men and seven interviews with their female colleagues.

Starting with an open question about how the men came to work in the nursery, we collected narratives about their entrance into the female-dominated organization, the changes or maintenance of organizational practices potentially resulting from his entrance, and the everyday work experiences of both the male and the female childcare workers (Gherardi and Poggio 2007). other questions in the semi-structured interview schedule were organized around the topics of work biography, daily practices of sharing labor, and individual preferences in pedagogical programs and daily activities. The interviews were conducted by the second author, digitally recorded and transcribed verbatim using a simplified version of the Jefferson system (Potter and Wetherell 1987) to capture non-verbal expressions, laughter, and silences where applicable.

To analyze the discursive practices involved in negotiating men's 'identity dissonance', we first read carefully through all interviews and coded the relevant passages according to our more general research questions (Wood and Kroger 2000). In a second reading, we more closely investigated the passages we had categorized with the codes 'doing gender difference'

3 The three year research project 'Dolls, building blocks and outdoor activity days: (un)doing gender in the nursery ' is funded by the Swiss National Foundation within the National Research Programme NRP 60 tackling issues of gender equality in Switzerland. For more information on the project and the NRP 60 please got to www.nrp60.ch. 
and 'doing gender sameness' to determine the discursive practices being applied as well as their consequences (Potter and Wetherell 1987). We analyzed subject positioning by identifying practices of self-making such as self-accounting, vocabularies of motives, culturally available stories for making sense, and emotional performances (Wetherell and Edley 1999, 338). In a case by case analysis, we then depicted the specific ways the men used the discursive practices, how they drew upon them in certain contexts in the interviews, and how this resulted in a specific management of identity dissonance. Throughout this analytical process, we four authors regularly discussed our interpretations with one another. These discussions enabled us both to shape our focus on the discursive practices and to ensure the intersubjective validity of our findings.

\section{Men in the nursery: Positioning as 'the same' and 'the other'}

In this section, we present our analysis of the discursive practices in nine interviews with male childcare workers. These men are positioned - and position themselves - both as 'the other' and as 'the same' and thereby manage the identity dissonance resulting from being a man working in a female-dominated occupation. Throughout our interviews we identified a total of six discursive practices that interviewees used to position themselves as a competent childcare worker and a man (see Table 1 for overview).

The six practices function differently. While three practices emphasize difference, two more promote sameness and one highlights professionalism. With regards to 'emphasizing difference', the first practice is that men (1) build 'male niches'. Within this discursive practice, they position masculinity as being in opposition to women and femininity. They do this by stressing the relevance of stereotypical masculine skills and interests such as playing football or engaging in rough and tumble play. In the second practice, men (2) draw on the subject position of the 'father' as a legitimate position within the family and hence an important relationship with children. A third practice positions masculinity as being in line with (3) the ideal of the 'male breadwinner'. Men emphasize their position in the hierarchy, or refer to concepts of career and breadwinning in any other way (Kelan 2008).

In emphasizing difference, they highlight positive aspects of being 'the other' in order to balance identity dissonance and achieve a legitimate position, meanwhile actively avoiding the highly negative and hence dangerous 'non-position' of the pedophile. In addressing the topic of sexually abusive behavior, practices that emphasize sameness become relevant. The fourth practice puts forward (4) equal rights and the importance of equality on a team. It is the major discursive practice these men use to cope with possible discrimination and the 
experience of exclusion. Practice number five is what Pullen and Simpson (2009) have called (5) 'appropriating femininity'. Men mention skills and interests that are generally depicted as feminine and claim them as appropriate and natural for themselves; by doing so they downplay the dissonance resulting from this perceived gap between masculinity and femininity. The final strategy that we found in our material moves beyond this binary structure of emphasizing either difference or sameness. By creating (6) the subject position of the pedagogue, men downplay gender and its relevance for legitimating the care taker's position; now professional skills and training come to the foreground (Hirschauer 2001).

\begin{tabular}{|l|l|l|}
\hline & Discursive practice & Results in \\
\hline 1 & Building the male niche & \multirow{2}{*}{ emphasizing difference } \\
\hline 2 & $\begin{array}{l}\text { Referring to the (symbolic) } \\
\text { position of the father }\end{array}$ & \\
\hline 3 & $\begin{array}{l}\text { Referring to the 'male } \\
\text { breadwinner' }\end{array}$ & \multirow{2}{*}{ emphasizing sameness } \\
\hline 4 & Emphasizing equality & emphasizing professionalism \\
\hline 5 & Appropriating femininity & Becoming a pedagogue
\end{tabular}

Table 1: Empirical findings: Six discursive practices and their consequences

One important finding from our analysis is that these men used nearly all six practices in all of the interviews. In fact, unlike the earlier studies we discussed above, we were not able to assign specific practices to distinctive men and their specific ways of narrating their situation in the nursery. Therefore, we will first introduce the practices in full detail and then discuss how they are combined and form distinctive sets of discursive maneuvers.

\subsection{Building the 'male niche'}

The first discursive practice, one that was very important throughout all the interviews, is building the 'male niche' (Williams 1989). This niche enables men to maintain a masculine identity when working in a female-dominated profession. Difference between men and women and their work is emphasized by means of several different, but still related, discursive devices that are all closely connected to what is perceived as stereotypical masculinity in terms of skills, tasks, and interests. The following extract stands as a typical 
example. Here Peter tells his story of starting to work at the nursery, describing the reactions of his female colleagues:

Interviewer: And your colleagues here?

Peter: Also very well! For a long time, I was the only man in this [name of] nursery and that was very very nice for them. To hand the kids over to someone who can sometimes handle the kids a bit tougher, to play those rough games, football, rough and tumble play, yes.

Interviewer: Was that also something you wanted to do? Or were you asked whether you could take that on, or - how should I imagine this process?

Peter: About football?

Interviewer: With the rougher play, I would say.

Peter: Okay, with the rougher play. Well no, it emerged. I don't know whether it is because of the role, which would somehow already be - inside me, which automatically makes a difference between man and woman, but somehow it was clear from the beginning, that I am responsible for the tougher things [laughs], indirectly.

Like the other male childcare workers we interviewed, Peter narrates his story of beginning work at the nursery as quite positive. He recalls that from the beginning he was very well integrated into the female team. He presents himself as an asset there, as his joining the team enabled them to hand over to him the 'harder games' such as playing football or other rougher play. Drawing on stereotypical differences between men and women, Peter is able to claim certain activities and a special educational style for himself. Thereby he constructs a legitimate position for himself as a man in this female-connoted occupation. In telling us that his colleagues were happy and also agreed (silently) to a gendered division of labour (Acker 1990), he lets us know that this was a consensual decision. In the following example, Michel also emphasizes gender differences:

Michel: Well, just for example rough and tumble play. That is something where they come to me and [ask] 'are we now going over to the nap room to do sports?' And that is the kind of role I tended to take on. And also I am more the one who enjoys nonsense and fun with the kids, and - and also sometimes forgets and says yes okay and with that I feel women are rather a bit $\mathrm{hmm}-$ set in their ways. That sounds a bit negative: 'set in their ways'. Or rather they have $\mathrm{hmm}$ - they have a bit more of a strict line - yes. And whether that is negative or positive, well one could argue about that, but I think that is the main difference.

By linking femininity to being somewhat settled and strict, Michel is able to position himself as the fun-loving guy who kids around and is more likely to engage in physical activities with the children. Just like Peter, by emphasizing skills and activities that refer to what can be depicted as stereotypical masculinity, he draws a boundary between masculinity and femininity that enables him to do masculinity.

This picture of 'the masculine' as bringing something different and complementary to the thus-far female-dominated world of the nursery is important in all our interviews. For 
instance, Peter creates a distinction between himself and the female apprentices in his way of comforting the children, distancing himself from what he calls the 'extreme forms of cuddling' that the women engage in. In another example, Sebastian explains that when a group of boys started fighting with sticks, he was the one who joined in, whereas his female colleagues were inclined to calm it down. Similarly, Reto emphasizes taking more risks when engaging in activities with the kids compared to his female colleagues. And Nick depicts women as being more anxious and men as being calmer in their interaction with children. Overall then, claiming skills, interests, and interaction styles that are stereotypically labeled as masculine is a common practice for gaining legitimacy as a man in the nursery. Difference is understood as enriching the female-dominated world of the nursery and hence as something positive.

\subsection{Referring to the (symbolic) position of the father}

These men further stabilized the legitimate position of men as bringing in something different as they referred to the role of the father in a heterosexual family. Throughout the interviews, they used this second discursive practice as a handy and effective reaction to our question about possible gender differences ('Do you have the impression that you do things differently, especially with the children?') as well as our attempt to interrogate men's potential role as innovators ('Is there something that you have tried to change since you started here?'). We included these questions in the interviews to open up the possibility for emphasizing difference. As a way of reacting to these challenges, the subject position of the father allows the interviewees to relate quickly to two major discourses. The first is the discourse of men as desperately needed to balance the female-dominated culture of early childhood education: men are seen as highly relevant for responding to boys' needs in general, but even more in the case of single mothers (Faulstich-Wieland 2012; Rohrmann 2009). Second, education, even in an institutional context, is closely connected with motherhood and the heterosexual family, especially when it comes to small children. Especially with regard to nurseries, the (heterosexual) family and the caring mother at home do serve as an ideal (Friis 2008; Rohrmann 2009). Thus, the position of the father is easily available as it is a counterpart to women on the one hand but is nonetheless a fitting and already existing position in the metaphor of the heterosexual family. In the following example, Nick highlights how parents responded positively to him serving as a male attachment figure.

Nick: I did not get any negative reactions, [but] rather positive ones, because there were also many single mums here or rather there still are, and for the children it is certainly not bad when 
they have a male caregiver day-to-day in the nursery.

Explicitly discussing the 'fatherless society' (Mitscherlich 1963) in the case of the single mother, Nick implicitly compares the positions in the heterosexual family with his position as a man working in a nursery. Although he is not a father himself, being a man seems to qualify him to substitute for the missing fathers. Hence, he is capable of compensating for this perceived lack and serves as a 'public father' (Aigner and Rohrmann 2012, 11). Here, being able to step into the father's position is perceived as a positive feature that is helpful in the contact with the parents. Again, becoming 'the other' is constructed as a major asset for the nursery.

Michel: I think that is the main difference, and there is also the role of the daddy, which happens again and again, when the child... For example, we had a separation, one or two months ago: an older couple separated and the child was mostly with the mother and then one could really notice that the child was seeking contact with me. That is an example of a situation where you could really notice the existence of that fatherly role.

For Michel the role of the father 'is present' through the reaction of a child whose parents had recently split up. Sebastian, on the other hand, emphasizes a dichotomous and essentialist understanding of masculinity and femininity that is legitimized through his association with the heterosexual nuclear family.

Sebastian: Well I find, I find that - I find it is just nice when there is a balance. Well somehow, I think, the ideal family really, essentially that is mother, father and child and so on, and that is rooted somewhere and that is why I think these are qualities, even as I could not really put it into words what I do differently.

Since he perceives mother, father, and child as the 'ideal family', he also believes that his presence as a man and (symbolic) father balances the so-far fatherless nursery. He thereby assumes that in the nursery the masculine and the feminine side of a family are both legitimate qualities. In this way he legitimates not only the position of the male caretaker, but also the existence of gender differences.

Although establishing the position of the father seems to work quite well in establishing legitimacy, it contains restrictions and brings with it some unwanted positions. This is problematic as it points to a private, non-professional role that assumes 'natural' skills and does not necessarily succeed in emphasizing the professional skills of child care workers. As they emphasize differences between women and men by referring to the father's position, interviewees succeed in creating legitimate positions. In doing so, however, they downplay 
the professional demands of workers in nursery education (Aigner and Rohrmann 2012; Rabe-Kleberg 2003).

\subsection{Referring to the 'male breadwinner'}

While the concept of 'building male niches' emphasizes men as being different compared to women, referring to the 'male breadwinner' positions men in comparison with an ideal masculinity. For instance, both Kelan (2009) and Meuser (2010) point to the close link between masculinity, career, and the male breadwinner. In a similar way, our interviewees refer to issues of career when talking about their occupational biographies. As early childhood education usually provides very limited career options, along with rather low pay and only part-time contracts, choosing a career in this field might challenge a man's masculine identity. As a possible reaction to these challenges we found men using typical career-related vocabulary like 'taking the next step' or being 'the boss'. For example, Paul talked about advancing in his career:

Interviewer: What was the entry process, how did you find this post?

Paul: In the [name of the nursery]? I wanted a change, I had already worked maybe twelve [years]. Since my training, I have always worked in a nursery run by the city. So that is why I came here. At the last nursery, [name], I was the group leader and responsible for the apprentices. And I wanted to take the next step, and that would be a deputy nursery head post.

Paul recalls his motivation for applying for his present job as a career matter: taking the next step, moving into the position of deputy manager of the nursery. Providing a brief overview of his professional experience so far, he presents himself as a senior and very experienced childcare worker. Although an expression like 'taking the next step' may be seen as unusual in the context of early childhood education, which is generally not hierarchical or career oriented, he manages to align his work biography with that of the ideal worker.

In a variation on the career topic, Jonas discusses his motivation for working full-time as a matter of career considerations. The nursery where he was working previously could offer only a part-time contract, so it 'was clear' to him that he should look out for something new. In both examples, the ideal of the male breadwinner is made relevant. While Paul refers to his interest in progressing to a higher position, Jonas emphasizes his aspirations of getting a fulltime position. In his reply to our question of why he thinks so few men actually opt for a career in early childhood education, he emphasizes men's position as breadwinners.

Jonas: I think as men, probably most of them want full time, well I think also as a woman [laughs] but I think from the perspective of men one rather wants to have a full-time post and earn 
enough - that still is the perception. I think that too, if I want to start a family, I would also first consider, 'do I have enough money', and not, 'does the woman have enough money'. And I think that has an influence, with the salary, and with the hours, well, that it is possible to work full time.

As today men still consider themselves to be the family's breadwinners, he assumes that the mediocre wages in early childhood education and the scarce opportunities for full-time work are relevant factors that keep men from entering the occupation. Although he admits that this might also be true for women, he considers it to be more important for men.

The three discursive practices presented so far all contribute to the same effect: negotiating the identity dissonance of being both 'the same' and 'the other' through emphasizing difference. By referring to specific masculine skills, introducing the position of the father, or drawing on issues of career advancement and wages, male childcare workers position themselves as the 'complementary other'. Something different happens with the next two practices - 'emphasizing equality' and 'appropriating femininity' - as we describe in the following paragraphs.

\subsection{Emphasizing equality}

While the first three discursive practices enabled men to construct a position for themselves as different but appreciated, and hence they defined being different as complementary, they also made difference relevant as something potentially unwanted and dangerous in their position. In particular the danger of being accused of pedophilia serves as a ready-made set of discourses that challenge men's position. This highly negative account constructs them as illmotivated and hence dangerous. Therefore men constantly need to foreclose the subject position of the pedophile. In fact, many interviewees draw boundaries between themselves and this position.

Although pedophilia is not necessarily part of the experience of any of these men or the nurseries where they work, and have worked, the danger of being accused of harming children influences the men's thinking and behavior. Being depicted as a potential danger serves as an 'imaginary position' (Wetherell and Edley 1999): although it is not necessarily grounded in personal experience, this position is highly relevant for their processes of subject positioning and identification.

However, as nurseries need to implement practices to protect children from potentially harmful interactions with caretakers, they put in place organizational rules that address the issue. What sounds like a straightforward and gender-neutral endeavor - protecting children often turns out to be directed only towards men. Therefore some of these men experienced the threat of being excluded from specific activities, of not being trusted, or of having to work 
under different rules from those of their female colleagues. For instance, Peter recalls a situation where he was no longer allowed to change the nappies of one particular child.

Peter: That really got to me. I was very very upset and also felt insulted, because there was no reason for that. And to create an order just to calm the parents: I think that is the wrong approach. Maybe, at the time, they should have called a parents' evening to look at it all, to address the topic and to see how they would want to handle it now that a man is working in the institution. But not just silence it and take away - well - rights.

As we see, the nursery manager became aligned with the parents' anxiety and mistrust instead of protecting her employee. Peter was very disappointed by this decision. In emphasizing his rights as an employee to do his job, which also includes being allowed to change nappies like anyone else, Peter is stressing equality as part of a strong case against the discrimination he experienced. Here, we see male childcare workers becoming the 'unwanted other' and 'emphasizing equality' as an important strategy for closing off this position.

Peter had to accept the new work conditions, and in fact later left this nursery for another job, because of this and other experiences. Nick also recalls a similar experience with parents' mistrust about changing nappies and other situations involving physical contact. However, Nick experienced a different reaction from his female colleague:

Nick: We had 12 or 13 kids all together, yes and there were two or three parents, or rather mothers - well exactly one was even a father - who were a bit skeptical. So at the beginning, they asked the group leader whether I also change nappies or take on tasks involving the body. And the group leader also passed that on to me but also discussed it with them and said that I am working absolutely normally, just like the others, and that we leave the doors open anyway, for both men and women, and that I have exactly the same regulations and the same areas of work as the female students, or apprentices. And that was then accepted and I then did, of course, seek the contact with the parents and well it is - I felt there was a certain - what can I say - perhaps a certain distance.

Because his female colleagues were supportive, together they were able to emphasize the normality of the tasks involved and the nursery's general guidelines for protecting children from abusive behavior, one being the practice of everyone leaving the door open when changing nappies. The support enabled Nick to rely on the same rules as the others and hence on equality in practice. However, the example also shows how powerful the position of the 'unwanted other' can be. As Nick still experienced some reservation from certain parents, he was regularly involved in dealing with these attributions of fear and mistrust. In fact, although he had 'officially' been granted equal rights, he would never have been able to become 'the same' as his female colleagues: that is, not at all a subject of suspicion. On the contrary, for men working as childcare workers, 'becoming unsuspicious' is an important everyday 
practice. As the example shows, by themselves, men cannot control whether they are perceived as 'the same' or 'the other'; their status depends strongly on the agreement and support of team leaders and nursery managers.

For most of the men we interviewed, the 'unwanted other' who is not allowed to change nappies serves as negative example. As our next example shows, the mere possibility of being positioned in an excluding way is problematic. Although Michel has never experienced discrimination - for instance special rules that would only apply to him as a man - the mere possibility already worries him.

Michel: Well, from the work I never had the feeling that I would somehow do something different; they never gave me the impression that I would somehow have a special - a special position, because I am a man. I was always treated the same, the same as all the women. I was allowed to do everything, was allowed to change nappies, I did all the tasks they also did. I have heard from other nurseries, where for example the men are not allowed to close the door when they change nappies, but that was not the case with me. I was trusted right from the beginning, and that was important to me: that I can do everything and that I have no special regulations. I guess that would have really made me worry.

'Emphasizing equality' is the major practice for re-installing men's legitimate position. Entirely disputing the legitimacy of special treatments, Michel is putting forward equality as the important general criterion: all employees must be treated the same and allowed to engage in the same kind of tasks. This practice minimizes the relevance of gender and the emphasis shifts to being a trained childcare worker.

\subsection{Appropriating femininity}

Becoming 'one of them' and hence emphasizing sameness is not only practiced in the sense of 'equal treatment' as discussed just above, but also as 'appropriating femininity' (Pullen and Simpson 2009). That is, the interviewed men claimed as a part of their personal identity some of the interests, skills, or personality characteristics that are traditionally perceived as feminine. By 'appropriating' these stereotypically 'female' attributes they were able to deconstruct the dissonance of being both 'the same' and 'the other'.

Interviewer: Well are there any changes, is there something, where you think you have introduced it here?

David: I think everybody, every team member plays their part, and their personal individual appreciations, every day, and then the kids and all that is formed into a whole, into that mix that constitutes our group. But I think there is nothing gender-specific that I would - have a special role as a man or so on. On the contrary [laughs] I think, well, Beate for example, she is rather wild and fidgety and fast and I am rather calm and sensitive I feel. 
By claiming 'calm and sensitive' as essential traits of his personality, and by positioning those qualities as in opposition to being 'wild and twitchy', which are typically perceived as masculine, David is switching the gender stereotypical ascriptions between himself and his female colleague. In addition, he is deconstructing the dissonance between being a sensitive person and being a man. This results in what others have called 'alternative masculinities' (Buschmeyer 2012; Cross and Bagilhole 2002). However, from the perspective of our material we cannot say that this practice is performed by a specific type of 'alternative' men. Like all the other practices we have analyzed, we found alternative masculinities in almost all of our interviews.

Michel, for instance, describes how he had to become familiar with an activity that is typically regarded as feminine: singing with the children. Although he says that like 'every man' in early childhood education he felt very uncomfortable with the task in the beginning, he now embraces it as part of the job and has even started to like it:

Michel: And then there is the singing of nursery rhymes, we then sing songs together. To me this was painful in the beginning [joint smiling]. I didn't really engage in this, this really was my sticking point, singing! That's not my pair of shoes. By now, luckily, I like doing it, yes, luckily today I am coming to terms with it. I also notice this with everybody new when they come in, especially the men. This is really an issue for ALL men, always. Every man who comes is in agony over the singing. ... Yes, it was obvious to me, that if I am to become a childcare worker, then I would do it right and then singing nursery rhymes is part of the full panoply, well, yes. It has been hard, and, well like 'peap peap peap' [expresses timidity] and then, yes, --- I simply thought this is the full panoply, like changing diapers, brushing [the kids'] teeth, and everything else.

Although he has had a hard time getting used to it, he emphasizes his strong belief that as singing is an important part of being a childcare worker, he simply had to get used to it. Here, embracing and then appropriating the female-connoted work areas can be read as putting gender differences into the background. In the same way, Peter, who had claimed rough and tumble play and football in particular as his domain within the nursery at the beginning of the interview, later 'appropriates femininity' when he emphasizes that he is rather interested in telling fairy tales and singing with the kids:

Interviewer: You just mentioned the games, football and so on. Is that something you introduced?

Peter: Less so. No, at the beginning yes. But as I am not so keen on football, to address the issue of football. No, that was more, when our apprentice came... he was so keen on football and he now plays with all the older boys from all the groups we've got, during the summer football all the time.

Interviewer: And are there any activities you think you like especially, which is perhaps your area of special expertise with the kids?

Peter: Yes, what I really like doing is singing and telling fairy tales. That is my thing, I have a 
lot of fun with that, yes.

Although Peter keeps intact the link between football and men, here he mitigates its relevance for his identity. While he had earlier positioned himself as the father and the complementary man, using 'playing football' as a discursive device to legitimate his position through emphasizing difference, he now speaks of football as less relevant, something he did not particularly care to pursue beyond his entrance phase. As David talked about being calm and sensitive, Peter's talk of singing and fairy tales becomes an expression of what is more in line with his true self. As a consequence, he modifies the identity dissonance as something not applicable here.

\subsection{Emphasizing the professional}

The final practice we discuss here is 'emphasizing the professional'. In this practice, the speaker does not mention gender, so it stays in the background, but he does emphasize his professional pedagogical skills, interests, or experiences. Men are enabled to construct (and draw on) a highly legitimate job-related position without running into danger of becoming the 'unwanted other'. Furthermore, pointing out pedagogical competencies enables men to refrain from stereotypical ascriptions of responsibilities or abilities to achieve a legitimate position. In our first example Paul describes his work in the nursery. What is impressive is that in contrast to most of the other childcare workers, he uses many technical terms to refer to his work.

Paul: I have to say, we have a tricky group dynamic at the moment. A 2-year- old who does not recognize any structures and a 4 1/2-year old who is still in nappies and at the developmental level of a 2 1/2-year-old and of course, these are the children we have to look after one to one. And then there are the other ten kids and so at the moment we are very structured and do a lot of planning: who looks after which kids and who is responsible for which transitions. We are relatively finely tuned. ... the $41 / 2$-year-old is bringing the whole group's dynamics to the point of collapse. Also, because he gets victimized and bullied, we are permanently working with the 4- and 5-year-old boys to protect him and to build him up.

In using terms like 'tricky group dynamic', 'structured planning', and the collapse of 'group dynamics', Paul emphasizes his professional knowledge. In doing so, he counters the discourse of the non-professional, family-like occupation of early child care. For instance, recalling how he had established a woodworking atelier in the nursery, he emphasizes his pedagogical goals and his professional approach:

Paul: Clearly, the main goals are always the educational aspects, with the kids, in terms of 
content and processes, to teach the craft, to build up the competence. And also to strengthen factors such as fine motor skills and so, yes, clearly I also enjoy crafts but such a project makes sense. I also produced a certificate with pictures and text. ... For example here, child $\mathrm{x}$ can take on this and this, and the date, like they passed the exam in the wood workshop. More on a symbolic level, yes?! But they need to know the basics, they need to know the rules and they need to know how to handle the tools, and then they get the certificate. And we also register that on a list within the group.

Working with professional goals and knowledge and using the technical terms of a professional in early childhood education, Paul manages to construct a legitimate position as a pedagogue. Having successfully built up a pedagogical offering that is now well established and utilized by his colleagues, he also positions himself as very deep-seated within the team.

In another example, Reto, who has received special training in running outdoor groups, emphasizes his specific pedagogy for working with children. Introducing us to a building site that he had set up in the nursery's garden, he also communicates his pedagogical concept.

Reto: To me on the one hand it is about nature, and on the other hand I also have a mobile building site. This is ... is really building materials, without anything being changed or adapted, directly taken here from the building site. Well I do not even take the nails out on the way here - the children will do that - and with the building site, that is to me a social building site, a life building site. They build themselves, and they all need imagination and they build something. They have to negotiate with each other, they have conflicts and they need to solve them and they also have to explore, explore, and then they discover materials that are concrete, and heavy, long, short, colors. And they build something and they are responsible for it themselves. What they build, no one else has done before. If they fall down or if it collapses, then they built it, they are responsible for what they make and they have to take the consequences directly. They can feel that and that is very important for me.

Here, Reto manages to specify goals for his pedagogical offers that are in line with the usual pedagogical goals like developing children's self-reliance. Through this work he is able to contribute to an accepted part of what is perceived as a regular pedagogical offering. By inventing metaphors such as 'social building site' he even succeeds in establishing his very special take on pedagogy.

Having expertise on an activity that is both well integrated into the nursery and can be presented as based on well-accepted pedagogical uses enables men to construct a legitimate position that involves professional knowledge, unlike, for instance, the private position of the father. For this reason, the position of the pedagogue is especially important for countering the unwanted position of the pedophile. Showing professional competencies and interest serves this purpose with the parents. In the next quote Michel elaborates on making contact with the parents in a way that would make them recognize his 'good motives': 
Michel: Well I think that if I had tried to be their best friend... that would have been difficult, and there is the worry that somebody would come in and say 'hey, let's just have fun'. I think that would have been a bit difficult, but because of the expertise I felt more secure in myself because I knew what I do and I knew what I talk about and they realized, hey he does this professionally and he does not just have fun with the kids and he hasn't got odd intentions or whatever, and he knows what he is talking about, he knows what he is doing. I think that was the only way to provide certainty for the parents.

Emphasizing pedagogical skills and interests enables men to create and make use of a legitimate position. Unlike the other five practices, in this one gender is not made relevant and the position of the pedagogue is potentially also accessible for women. Nevertheless, the practice of 'becoming the pedagogue' does not move beyond gender. For instance, through positioning himself as the pedagogue, Paul also establishes a hierarchical relationship between himself and his female colleagues. While the position of deputy nursery manager is not usually connected to any specific responsibilities as long as the manager is present, Paul uses considerable detail to successfully construct his role as being the one in charge.

Paul: And there you also need a lot of energy to be the go-between, to mediate between the team and the boss. And I had many talks in the breaks where I also addressed the issue with the person concerned. This is your group, you have resigned, you are leaving in two months, but look at how it is going with conflicts at the moment - where is your group?

Describing the role he played in a severe conflict between the nursery's manager and the team of childcare workers, Paul positions himself as the conflict manager, emphasizing professional competencies such as his far-sightedness, giving good advice to his female colleagues and functioning as the children's advocate. He thereby manages to practice 'heroic masculinity' (Wetherell and Edley 1999), which culminates in his referring to himself as being 'the ground' whereas the nursery manager was degraded to being 'just responsible for the organizing part'.

Similarly, Reto constantly relies on the position of pedagogue to legitimate his position. But a clear masculine connotation emerges in the way he describes his pedagogical style. Emphasizing his special pedagogical training and his competence in managing a group, staying in control, and keeping it all on track, he positions himself not only as a highly skilled and competent pedagogue, but also as superior to his female colleagues. Thanks to his pedagogical competences, he says, he will be the one who maintains the overview, while his female colleagues would tend to micro-manage the children.

Reto: Here, outdoors, outdoors is clearly my responsibility. Well the nursery staff we have here, maybe also because of their training, ... I am able to keep the group together, to keep the overview, the control and it is my training, how I learnt the subject from my colleagues, that I let them be 
sometimes, let them free, don't try to [supervise] in every corner. It takes some courage to let it be, it is difficult yes. But it also developed that way, I think. I do not interfere with them ....

The examples of both Paul and Reto show that while the position of the pedagogue is potentially available for both male and female childcare workers and could therefore be a position that moves beyond the identity dissonance of being 'the other' and 'the same', it is primarily used here in ways that reproduce the gender binary through hierarchies. As a result, the discursive practice of 'becoming the pedagogue' succeeds in establishing a legitimate and also stable subject position; nevertheless the practice re-establishes gender differences, though in a more subtle way.

\section{Discussion: Male childcare workers maneuvering for a legitimate position}

Our analysis of male childcare workers managing identity dissonance has resulted in six distinctive discursive practices (see Table 1). These are: (1) 'building the male niche', (2) 'positioning oneself as the father', (3) 'referring to the male breadwinner', (4) 'emphasizing equality', (5) 'appropriating femininity', and (6) 'becoming a pedagogue'. While all these practices are relevant for negotiating identity dissonance, they do so differently and with different consequences, with regards to both subject positioning and coping with identity dissonance.

Within practices that 'emphasize difference', masculinity is positioned as either complementary to femininity or as compliant with the ideal of the male breadwinner. Male childcare workers position themselves as having special and complementary skills and interests (in the 'male niche') and depict themselves as comparable to fathers. By doing so they draw on the strong discourse of the heterosexual family, associating women with mothers and men with fathers (Nentwich 2008). These two practices have similar consequences and are complementary to each other: they legitimate both men's position and their interest in the topic. However, with regards to identity dissonance, they succeed in managing difference but do not move beyond it. Although they help men to legitimate their position, the men are not seen as equivalent to women but only as suitable in their special niche with a special assignment and objective. Furthermore, when a man positions himself as a father, he may even wind up minimizing his necessary professional competence, emphasizing the 'natural' skills and abilities of being a father.

Emphasizing difference can also become dangerous if the difference is interpreted in a negative way, as can happen when the discourse of pedophilia casts its cloud. Hence, the subject position of the 'complementary other' constantly requires discursive maneuvering to 
gain stability. In that vein, 'positioning as a father' can be interpreted as a practice that aims at 'healing' the dangerous side of 'complementary otherness'. Similarly, 'emphasizing sameness' can come into play for managing the negative attributions of otherness.

The third practice that emphasizes differences, 'referring to the male breadwinner', is less concerned with being complementary to women and more with being compliant with an ideal masculinity. Men tend to position themselves as interested in a career, to emphasize their role as breadwinners, or to refer to themselves as being 'the boss'. They also emphasize hierarchies and their status within them. Through such moves men succeed in positioning themselves as 'real men', 'healing' the potential challenge of their masculinity. This practice serves to bolster a (traditional) masculine identity.

With regards to 'emphasizing sameness' we found two major practices in our material. The first one, 'emphasizing equality', was activated as a direct response to any questioning of men's integrity. By referring to the powerful discourse of equal treatment, they were able to immediately counter any doubts about their insincerity and to prevent potential damage. It is important to note that 'sameness' is understood here as 'being treated the same' and hence equality. On the other hand, 'appropriating femininity' also emphasizes sameness, but those using it aim instead at 'becoming the same'. This practice is an important device for coping with identity dissonance and men used it successfully to build a legitimate position for themselves as workers in nurseries. However, it is interesting to note that men claiming typical feminine skills and interests for themselves would also cite the male breadwinner. While 'appropriating femininity' seems to allow them to become 'one of them', referring to accounts of hegemonic masculinity seems to keep them from having their masculinity questioned.

Finally, we come to the position of the pedagogue. Similar to 'emphasizing equality', this practice establishes a seemingly gender-neutral subject position that leaves identity dissonance behind as something that seems irrelevant and therefore remains in the background. As a consequence, gender differences are minimized and individual differences, for instance in personalities, skills, and interests, are emphasized. New spaces for subject positions in childcare work are created. However, because it mobilizes the 'male breadwinner', gender comes in again, resulting in the re-establishing of the hierarchy between masculinity and femininity.

Through our analysis we found that the six discursive practices provide different solutions for men aiming to handle identity dissonance and the challenge of either becoming the ‘dangerous man' or 'endangering masculinity'. Unlike Cross and Baghilhole (2003) and 
Buschmeyer (2012), we found all these practices in almost all the interviews and it is impossible to say that any one practice is especially suitable for one interviewee. Nevertheless, we did identify specific patterns in the ways these practices are used and also combined through the course of one interview. As none of the practices secures a stable, fixed, and unassailable subject position, men have to continuously maneuver between positions in order to legitimate their position. For instance, when a man works on building the male niche, he immediately has to use mitigating practices such as emphasizing equality or taking the position of the father in order to avoid being seen as engaged in dangerous differences; he may also turn to accounts of 'male breadwinning' in order to avoid having his masculinity questioned. Similarly, men need mitigating practices when they are 'appropriating femininity' as doing so might result in endangering masculinity. Throughout all the interviews, we saw interviewees shift from one position to the other in these ways.

While efforts to emphasize difference require other practices in order to balance and rebalance the dilemma, a man can leave that dilemma in the background by moving beyond gender and emphasizing his professionalism. Then he no longer needs to either maneuver or shift between repertoires and positions. By emphasizing professionalism men can draw on a legitimate account in the field of nursery education without placing their gender identity into question.

As a result, this practice requires fewer mitigating practices than the others. Interestingly, in our sample the subject position of the pedagogue is mainly available to older and more experienced men; young men who have just finished their training are more likely to shift between repertoires or maneuver between positions. Therefore, developing an account that leads to a stable position might be crucial for keeping one's job in the female-dominated profession. Developing a position that does not struggle with identity dissonance but leaves it behind seems to be the most promising way to build a legitimate position. 


\section{Literature}

Acker, J. 1990. "Hierarchies, Jobs, Bodies: A Theory of Gendered Organizations." Gender \& Society 4 (2): 139-158.

Aigner, J. C., and T. Rohrmann. 2012. “Einführung: „Public Fathers” - Männer in pädagogischen Berufen. "In Elementar-Männer in der pädagogischen Arbeit mit Kindern, edited by Aigner, J. C. and T. Rohrmann, 11-16. Opladen: Barbara Budrich.

Budig, M. 2002. "Male Advantage and the Gender Composition of Jobs: Who Rides the Glass Escalator?" Social Forces 49 (2): 258-77.

Buschmeyer, A. 2012. Zwischen Vorbild und Verdacht - wie Männer im Erzieherberuf Männlichkeit konstruieren. Wiesbaden: VS Verlag für Sozialwissenschaften.

Cameron, C. 2001. "Promise or Problem? A Review of the Literature on Men Working in Early Childhood Services.” Gender, Work and Organization 8 (4): 430-453.

Cross, S., and B. Bagilhole. 2002. "Girls' Jobs for the Boys? Men, Masculinity and Nontraditional Occupations." Gender, Work and Organization 9 (2): 204-226.

Davies, B., and R. Harré. 1990. "Positioning: The Discursive Production of Selves.” Journal for the Theory of Social Behavior 20 (1): 43-63.

Edley, N., and M. Wetherell. 1997. "Jockeying for Position: The Construction of Masculine Identities." Discourse \& Society 8 (2): 203-217.

Edley, N., and M. Wetherell. 1999. “Imagined Futures: Young Men's Talk about Fatherhood and Domestic Life.” British Journal of Social Psychology 38 (2): 181-194.

Edley, N., and M. Wetherell. 2001. 'Jekyll and Hyde: Men's Constructions of Feminism and Feminists." Feminism and Psychology 11 (4): 439-457.

Epstein, C. 1992. "Tinkerbells and Pinups: The Construction and Reconstruction of Gender Boundaries at Work." In Cultivating differences. Symbolic boundaries and the making of inequality, edited by M. Lamont and M. Fournier, 233-256. Chicago: University of Chicago Press.

Faulstich-Wieland, H. 2011. „Werden tatsächlich Männer gebraucht, um Bildungsungleichheiten (von Jungen) abzubauen?“ In Geschlechtsspezifische Bildungsungleichheiten, edited by A. Hadjar, 393-415. Wiesbaden: VS Verlag für Sozialwissenschaften.

Faulstich-Wieland, H. 2012. „Sollten Grundschullehrer vor allem Vorbild für Jungen sein? Zusammenhänge zwischen Studienmotivation von Lehramtsstudierenden, Diskursen um „mehr Männer in die Grundschule“ und Perspektiven guter (Grund-)Schulen.“ In 
Männer und Grundschullehramt, edited by S. Hastedt and S. Lange, 13-30. Wiesbaden: VS Verlag für Sozialwissenschaften.

Friis, P. (Y. Rakbjörg \& T. Rohrmann, trans.) 2008. Männer im Kindergarten. Wie man sie anwirbt - und dafür sorgt, dass sie auch bleiben. Themenheft des norwegischen Kultusministeriums, 2006. Forschungsprojekt Elementar: Universität Innsbruck.

Foucault, M. 1972. The Archaeology of Knowledge. London: Tavistock.

Gherardi, S., and B. Poggio. 2007. "Gendertelling in Organizations. Narratives from Maledominated Environments.” Fredriksberg: Liber: Copenhagen Business School Press.

Gill, R. 2000. "Discourse Analysis." In Qualitative Researching with Text, Image and Sound: A Practical Handbook for Social Research, edited by M. W. Bauer and G. Gaskell, 172-190. London: Sage.

Heintz, B., E. Nadai, R. Fischer, and H. Ummel. 1997. Ungleich unter Gleichen. Studien zur geschlechtsspezifischen Segregation des Arbeitsmarktes. Frankfurt a.M.: Campus.

Hirschauer, S. 2001. "Das Vergessen des Geschlechts. Zur Praxeologie einer Kategorie sozialer Ordnung." In Geschlechtersoziologie, edited by B. Heintz, 209-235. Wiesbaden: Westdeutscher Verlag.

Hultin, M. 2003. "Some Take the Glass Escalator, Some Hit the Glass Ceiling? Career Consequences of Occupational Sex Segregation.” Work and Occupations 30 (1): 3060.

Kelan, E. 2008. "Gender, Risk and Employment Insecurity: The Masculine Breadwinner Subtext." Human Relations 61 (9): 1171-1202.

Kelan, E. K. 2010. "Gender Logic and (Un)doing Gender at Work." Gender, Work \& Organization 17 (2): 174-194.

Lupton, B. 2000. “Maintaining Masculinity: Men Who do 'Women's Work'.” British Journal of Management 11 (4): 33-48.

Martin, P. Y. 2001. "Mobilizing masculinities: Women's experiences of men at work." Organization 8: 587-618.

Maume, D. J. 1999. “Glass Ceilings and Glass Escalators. Occupational Segregation and Race and Sex Differences in Managerial Promotions.” Work and Occupations 31 (2): 250274.

McDonald, J. 2012. "Conforming to and Resisting Dominant Gender Norms: How Male and Female Nursing Students Do and Undo Gender." Gender, Work \& Organization. Online early DOI:10.1111/j.1468-0432.2012.00604.x. 
Meuser, M. 2010. “Geschlecht, Macht, Männlickeit - Strukturwandel von Erwerbsarbeit und hegemoniale Männlichkeit.” Erwägen Wissen Ethik 21 (3): 325-336.

Mitscherlich, A. 1963. Auf dem Weg zur vaterlosen Gesellschaft. München: Piper.

Murray, S. B. 1996. “We All Love Charles': Men in Child Care and the Social Construction of Gender". Gender \& Society 10 (4): 368-385.

Nadai, E., P. Sommerfeld, F. Bühlmann, and B. Krattiger. 2005. Fürsorgliche Verstrickung. Soziale Arbeit zwischen Profession und Freiwilligenarbeit. Wiesbaden: VS Verlag für Sozialwissenschaften.

Nentwich, J. C. 2008. "New fathers and mothers as gender trouble makers? Exploring discursive constructions of heterosexual parenthood and their subversive potential." Feminism and Psychology 18 (2): 207-230.

Nentwich, J. C., and E. K. Kelan. forthcoming. "Towards a topology of doing gender: A review on empirical research and its challenges." Gender, Work and Organization.

Pilgeram, R. 2007. “'Ass-kicking' Women: Doing and Undoing Gender in a US Livestock Auction." Gender, Work \& Organization 14 (6): 572-595.

Potter, J., and M. Wetherell. 1987. Discourse and Social Psychology: Beyond Attitudes and Behaviour. London: Sage.

Pullen, A., and R. Simpson. 2009. "Managing Difference in Feminized Work: Men, otherness and Social Practice.” Human Relations 62, 561-587.

Rabe-Kleberg, U. 2003. Gender Mainstreaming und Kindergarten. Weinheim: Beltz.

Rohrmann, T. 2008. Zwei Welten? Geschlechtertrennung in der Kindheit. Forschung und Praxis im Dialog. Opladen and Farmington Hills: Budrich Uni Press.

Rohrmann, T. 2009. Gender in Kindertageseinrichtungen. Ein Überblick über den Forschungsstand. München: Deutsches Jugendinstitut.

Sargent, P. 2005. "The Gendering of Men in Early Childhood Education.” Sex Roles 52 (3/4): 251-260.

Simpson, R. 2004. "Masculinity at Work.” Work, Employment \& Society 18 (2): 349-368.

Simpson, R. 2009. Men in Caring Occupations: Doing Gender Differently. Basingstoke: Palgrave.

Vogt, F. 2002. "A caring teacher: Explorations into primary school teachers' professional identity and ethic of care." Gender and Education 14(3): 252-264.

Warin, J. 2006. "Heavy-metal Humpty Dumpty: Dissonant Masculinities within the Context of the Nursery." Gender and Education 18 (5): 523-537. 
Wetherell, M., and N. Edley. 1999. "Negotiating Hegemonic Masculinity: Imaginary Positions and Psycho-discursive Practices.” Feminism and Psychology 9 (3): 335356.

Williams, C. L. 1989. Gender Differences at Work: Women and Men in Nontraditional Occupations. Berkeley and Los Angeles: University of California Press.

Williams, C. L. 1992. "The Glass Escalator: Hidden Advantages for Men in the 'Female' Professions." Social Problems 39 (3): 253-267.

Williams, C. L. 1995. Still a Man's World: Men who do "women's work." Berkeley: University of California Press.

Wood, L. A., and R. O. Kroger. 2000. Doing Discourse Analysis: Methods for Studying Action in Talk and Text. London: Sage. 